\title{
THIOMOLYBDATE - THE MAJOR FACTOR ON CLINICAL COPPER DEFICIENCY
}

\author{
M.R.Sanjabi ${ }^{1}$, M.M.Moeini ${ }^{2}$, S. B.Telfer ${ }^{3}$ \\ ${ }^{1}$ Department of Animal Science, IROST, Tehran, IRAN. ${ }^{2}$ Dep. Animal Science, Razi University, Kermanshah,
IRAN. ${ }^{3}$ Dep. Animal Physiology \&Nutrition, Leeds University, Leeds, UK.
}

The availability of copper to ruminant animals is greatly influenced by the molybdenum, sulphur; and iron content of diets. It has long been known that molybdenum is involved in $\mathrm{Cu}$ deficiency (Phillipo et al, 1987; Bremner et al, 1987; Hurley and Doane, 1989; Moeini et al.1997). The purpose of this study was to examine the effects of a low copper diet (less than $1.6 \mathrm{mg} / \mathrm{kg} \mathrm{DM}$ ) and also with additional molybdenum, iron and sulphur on the copper status in two breeds of sheep.

Four 1 year -old Suffolk cross Mule white sheep (live weight 34 - $43 \mathrm{Kg}$ ) and Four 7 to 9 months old Scottish black Hebridean castrate sheep were fed a low copper diet in a pelleted form over 17 weeks period. This diet was a modification of that described by Mills et al (1976) with oat husk replacing cellulose. This basal diet had a mean copper content of less than $1.6 \mathrm{mg} \mathrm{Cu} / \mathrm{kg} \mathrm{DM}$. In order to increase the molybdenum, sulphur and iron of the diet, molybdenum was added as ammonium molybdate $\left(\mathrm{NH}_{4}\right)_{6} \mathrm{MO}_{7} \mathrm{O}_{24} \cdot 4 \mathrm{H}_{2} \mathrm{O}$ ), while sulphur and iron were added as $\left(\mathrm{NH}_{4}\right)_{2} \mathrm{SO} 4 \mathrm{AND} \mathrm{FeSO}_{4} \cdot 7 \mathrm{H}_{2} \mathrm{O}$ respectively. Feed samples were analysed for minerals $\mathrm{Mo}, \mathrm{Fe}, \mathrm{S}$ and $\mathrm{Cu}$ content by Inductive coupled plasma (ICP). Changes in liver and blood copper concentration and in the copper-containing enzymes; caeruloplasmin (CP) and superoxide dismutase (SOD) activities were monitored by standard methods described by Mackenzie et al, (1997). Statistical analysis of the results was carried out using student $\mathrm{T}$ test and analysis of variance (one way).

The results showed that the occurrence of $\mathrm{Cu}$ deficiency depends not only on the low content of this metal in an animals diet, but also on the presence of interacting other minerals, especially molybdenum, sulphur and iron. Although the blood copper and liver copper concentration decreased in all sheep fed a low copper diet no clinical signs of deficiency were observed over 17 week period. The response of the animals to the dietary alteration depends on the liver copper concentration and breed. The black Hebridean Sheep were more susceptible than Suffolk sheep showing clinical copper deficiency. The mean overall balance results for the black and white sheep were -0.063 and $+0.013 \mathrm{mg}$ $\mathrm{Cu} /$ day respectively over this 17 weeks depletion period. The values of total plasma copper and TCA soluble copper plasma and copper related enzymes (SOD, CP) are shown in figures. The plasma copper levels for the white sheep during the initial depletion period ranged from 10.8 to $17.8 \mu \mathrm{mol} /$ and for the black sheep were lower with the range being $6-14 \mathrm{mmol} / \mathrm{l}$. There were no significant differences between the copper plasma and TCA soluble copper plasma during this phase of the experiment. However the addition of molybdenum $(5 \mathrm{mg} / \mathrm{kg} \mathrm{DM})$, iron $(600 \mathrm{mg} / \mathrm{kgDM})$ and sulphur $(3 \mathrm{~g}$ $/ \mathrm{kg} \mathrm{dm}$ ) to this diet after 2-5 weeks did produce clinical copper deficiency with dipigmentation of wool and poorer crimp being observed.

In third phase of the experiment when the diet was further modified by the removal of the molybdenum but still with $600 \mathrm{mg} / \mathrm{kg}$ DM iron and 3-g/kg DM sulphur, there was a decrease in blood copper but no clinical symptoms were observed. This is in agreement with Humphries et al. (1983), Bremner et al. (1987) and SUTTLE (1991) who showed that iron can act as a potent antagonist of copper and can also severely reduce the concentrations of copper without producing clinical symptoms of copper deficiency. 
It can be concluded that the specific effect of molybdenum in producing clinical copper deficiency symptoms can be detected when molybdenum combined whit sulphur and passes through into blood which can deactivated $\mathrm{Cu}$ enzymes and the clinical signs are likely to be from thiomolybdate (MoS4) in the body. The only way to stop thiomolybdate toxicity through CuMoS4 complex formation is to provide a more available form of copper supplement.

\title{
References
}

Mackenzie, A.M., Illingworth, D.V., Jackson, D.W. and Telfer, S.B.(1996). A comparison of methods of assessing copper status in cattle. In: Trace elements in Man and Animals:Tema-9,(In Press).

Maff, (1986). Ministry Agri. Fish. Food. The analysis of Agriculture materials.ref 427.

Mills, C. F., (1980). Metabolic interaction of copper with other trace element. In Biological Roles of Copper.Ciba. Found. Symp.79. Excerpta Medica, Amesterdam, Neth. p 49.

Woolliams, C., Suttle, N. F., Woolliams, J. A., and Wiener, G., (1986). Studies on lambs from lines genetically selected for low and high copper status. Animal Prod. 43, 293.

\section{A PRELIMINARY STUDY ON SELENIUM CONCENTRATIONS IN FECES OF FATTENING PIGS FED SELENIUM-SUPPLEMENTED DIET}

\author{
Theera Rukkwamsuk, Kittisak Chaisawat, Pichet Phukboa, Prayard Khengka, \\ Weerawong Prayoonshatpan, and Churee Pankamnerd
}

Faculty of Veterinary Medicine, Kasetsart University, Kampangsaen, Nakhon-Pathom 73140 Thailand

Selenium (Se), a trace mineral, plays a crucial role together with vitamin E in antioxidant mechanism, and is important for normal animal growth. In pigs, it has been a common practice to supplement Se in the diet of fattening pigs. However, it is interesting to concern whether the current Se supplementation is in excess of dietary needs, which would simply influence the contamination of Se in the environment. The objective of this study was to determine the concentrations of selenium in the feces of 3 fattening pigs that were fed a control diet and a Se- supplemented diet. During 17 days of the experiment period, the three pigs were fed the control diet for 5 days, the Se-supplemented (200 $\mathrm{ppm}$ ) diet for 7 days, and the control diet for the last 5 days, respectively. Feed intake was recorded
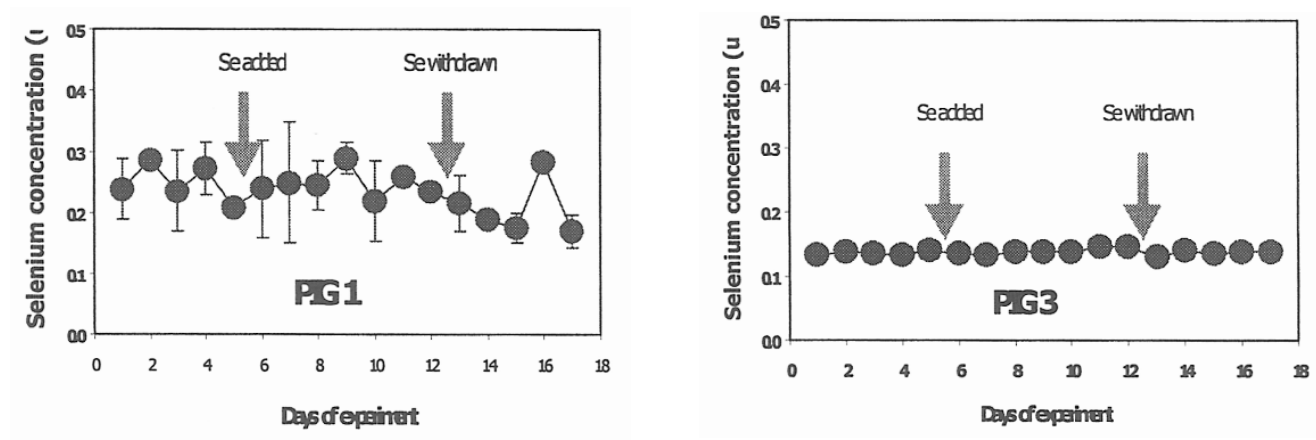

Figure 1. Selenium concentrations in the fecal samples of the three fattening pigs during the 17 days of experiment. 
daily, and was analyzed for dry matter intake. Fecal samples were collected per rectum daily, and were analyzed for Se concentrations by using spectrofluorometric method. Our results revealed that dry matter intake per day of all pigs was not altered during the experimental period, indicating that changing the diet in a short period did not influence the feed intake of the pigs. The Se concentrations in the fecal samples of all pigs were not changed during the experimental period (Figure 1), which might imply that Se-supplementation at the dose of $200 \mathrm{ppm}$ did not result in increased excretion of Se in the feces.

In conclusion, supplementation of Se at the recommendation dose (200 ppm) did not alter the feed intake of pigs as well as did not increase excretion of Se via gastrointestinal tract.

\title{
EFFECTS OF PHOSPHORUS IN THE PREVENTION OF SAVOY CABBAGE POISONING IN CATTLE
}

\author{
Nouri.M, Jalali.M.R, Somti.M and Gharaje.B
}

Dept. Of Clinical Science, Faculty of Veterinary Medicine, Shahid Chamran University, Ahwaz, Iran.

Kale poisoning is one of the important natural hepatotoxins. And it is well know where these plants are grown for fodder and in same areas it is no longer used because of the danger. The overall prevalence of poisoning is probably not great but on individual forms the number affected is usually significant, and the mortality rate is high.

In this study, the effects of kale poisoning and administration of organic phosphorus on preventation of toxic effects of this plant in cow were studied.

This study was performed on 4 native heifers. The animals were divided in two groups.

Clinical signs were examined daily and blood samples were collected every other day.

The blood samples were used to determine values of $\mathrm{Hb}, \mathrm{PCV}, \mathrm{RBC}, \mathrm{MCV}, \mathrm{MCH}, \mathrm{WBC}$, billirubin, AST, ALT and ALP. The levels of blood phosphorus were measured, too.

In group one, 2 heifers were fed only by savoy cabbage. These animals show hemoglubinuria and elevation of serum enzymes (AST, ALT\&ALP) and bilirubin after 12-13 days. The heinz body were seen in the blood smears before the observation of hemoglubinuria. Also, PCV, Hb and RBCs decreased. At this time, the level of blood phosphorus was below normal.

In group two, 2 heifers were fed only by Savoy cabbage but an injection of organic phosphorus were administrated when the level of blood phosphorus reached below normal. After three month these animals (group 2) didn't show the clinical signs of toxicity and the Heinz bodies were not seen in the blood smears. The blood levels of the serum enzymes and other parameters were normal.

We confirmed that there is a correlation between the level of blood phosphorus and the progression of the kale poisoning. So the injection of organic phosphorus can prevent or at least delay the kale poisoning. It is just in accordance with results of previous studies reported in the literature.

1. Heaney-RK. et al (1995): Natural toxins and protective factors in Brassica Species including rape seed. Natural toxins, 3:4, 233-237 record.1980, 107:1, 12-15

2. Taljaard,TL (1993) Cabbage Poisoning in ruminant. Journal of the south African Veterinary association, 64:2, 96-100 